\title{
Assimilação intrassegmental em Kaingáng
}

\author{
Aryon D. Rodrigues \\ Marita Porto Cavalcante
}

A língua Kaingáng apresenta segmentos fonológicos complexos, os quais se caracterizam pela alternância dos valores de certas propriedades distintivas. O caso mais proeminente é o dos segmentos vozeados que apresentam sequências dos valores positivo e negativo da propriedade [nasal]. Como representação básica desses segmentos propomos a especificação complexa [+++vozeado/-+-nasal], a qual se realiza efetivamente quando qualquer desses segmentos se acha entre vogais orais. A partir dessa representação básica, que comporta três fases sucessivas de realização das propriedades [vozeado] e [nasal], regras de assimilação operam de modo a conformar os valores dessas propriedades numa ou em mais de uma fase com os valores das mesmas propriedades em segmentos vizinhos.

Assim, em vez de assimilar-se um fonema a seus vizinhos apenas segundo cortes, por assim dizer, horizontais em seu feixe de propriedades fonéticas, de modo que cada propriedade seja tratada como uma unidade indivisível (o que tem sido a única situação considerada pela fonologia), no Kaingáng há fonemas que se assimilam também mediante cortes verticais, que afetam somente uma ou duas fases da realização de suas propriedades distintivas. $\mathrm{O}$ tratamento proposto para os segmentos complexos do Kaingáng é aplicável a outros segmentos complexos que têm até agora oferecido dificuldade à análise fonológica, como os fonemas africados, os ditongos, os fonemas prénasalizados. 